\title{
Keats's Letters and Lamia
}

\author{
Chunhong Yang \\ North China Electric Power University
}

\begin{abstract}
Keats's Lamia is known for its ambiguity, but critics fail to trace its cause. In Keats's Letters, he reveals his split attitudes to women, similar to his ambiguous feelings towards Lamia. From his Letters, his creation of an ambivalent beauty is understood.
\end{abstract}

Key words: Lamia, Letters, ambiguity

\section{INTRODUCTION}

Critics have universally recognized Lamia to be an enigmatic and ambivalent poem since the identity of Lamia is hard to define. Andrew Bennett in Keats, Narrative and Audience [1994] reads Lamia as "allegory of reading" and views Lamia as "a figure for the poem itself" [173, 176].So far, Bennet also presents us a rather comprehensive summary of the readings of Lamia. Most of the readings focus on the allegorical interpretations of the three characters, so the summary is offered in a threefold division as follows:

$\begin{array}{lll}\text { Lamia } & \text { Lycius } & \text { Apollonius } \\ \text { Fanny Brawne } & \text { Keats } & \text { Charles Brown } \\ \text { Poetry } & \text { Poet } & \text { Philosopher } \\ \text { Poem } & \text { Keats/Poet } & \text { Reviewers } \\ \text { Illusion/Dream } & \text { Dreamer } & \text { Reason/Reality Principle } \\ \text { Id } & \text { Ego } & \text { Superego } \\ \text { Text } & \text { Reader } & \text { Public }\end{array}$

Although the summary came out in 1994, it sums up most of the critics' opinions. The poem is rich with implications. But critics fail to find out the cause of the ambiguity of Lamia. With the help of Keats's letters, the paper tries to analyze Keats's attitudes to women in real life and in Lamia, and then his creation of ambiguous Lamia will be understood.

\section{In Letters}

\section{KEATS AND WOMEN}

As John Whale observes, "On the evidence of his letters, Keats's attitude to women seems to share the doubleness of perspective. He sees them from the position of a 'man of the world'with all that the phrase implies-as well as from the position of an 'Eternal being'" [19]. His letters reveal his ambivalent attitudes to women, similar to his portrayal of Lamia.

One of his most revealing and most disturbing commentaries on his attitude towards women occurs in a letter to his friend Benjamin Bailey dated 18 and 22 July 1818. There's a surprising degree of candor here and it is coupled with an unusual degree of self-diagnosis.

I am certain I have not a right feeling towards Women-at this moment I am striving to be just to them but I cannot-Is it because they fall so far beneath 
my Boyish imagination? When I was a Schoolboy I though[t] a fair Woman a pure Goddess, my mind was a soft nest in which some one of them slept though she knew it not-I have no right to expect more than their reality. I thought them ethereal above Men-I find then perhaps equal-great by comparison is very small-Insult may be inflicted in more ways than by Word or action-one who is tender of being insulted does not like to think of an insult against another-I do not like to think insults in a Lady's Company-I commit a Crime with her which absence would not have not known-Is it not extraordinary? When among Men I have no evil thoughts, no malice, no spleen-I feel free to speak or to be silent-I can listen and from every one I can learn-my hands are in my pockets I am free from all suspicion and comfortable. When I am among Women I have evil thoughts, malice spleen-I cannot speak or be silent-I am full of Suspicions and therefore listen to no thing -I am in a hurry to be gone-You must be charitable and put all this perversity to my being disappointed since Boyhood-yet with such feeling I am happier alone among Crowds of men, by myself or with a friend or two-With all this trust me Bailey I have not the least idea that Men of different feelings and inclinations are more short sighted than myself. [Letters, I, 341]

Some of the key terms and structures of Keats's representation of women and gender relations are already clearly evident in this honest confession to a friend. In the letter, Keats confesses his split views between woman as idealized, imaginary and ethereal, and woman as she is in the reality, and the cause of the split is that women cannot meet his "Boyish Imagination". Furthermore, what the passage also most spectacularly reveals is the degree to which Keats is disturbed by the figure of woman: a figure, as he articulates it, which inhabits the fault-line of his idealism. Keats's response to women here produces negative thoughts which he goes as far as defining as "crime", "evil" and "malice". Perhaps the most surprising-as well as the most healthy-is his recognition that this is "perversity". Typically, his response is to retreat into the company of men-either in "crowds" or by himself "with a friend or two". Therefore, isolation or among men are equally preferable to the company of woman to the anxious Keats.

Only a month earlier, Keats had written to Bailey explaining how his extremely close relationship with his brothers had determined his attitude to women: "My love for my Brothers from the early loss of our parents and even for earlier Misfortunes has grown into a affection 'passing the love of Women' - I have been ill temper'd with them, I have vex'd them-but the thought of them has always stifled the impression that any woman might otherwise have made upon me"[Letters, I, 293]. Here, Keats once again signals his commitment to a form of male bonding.

The same anxious withdrawal from contact with women and from the standard social expectations of marriage is evident in a brief passage from a letter to his brother George in October 1818. It begins with a typical Keatsian expression of self-isolation and self-absorption:

I melt into the air with a voluptuousness so delicate that I am content to be alone-Things combined with the opinion I have of the generality of womenwho appear to me as children to whom I would rather give a Sugar Plum than my time, from a barrier against Matrimony which I rejoice in.[...] You see there is nothing spleenical in all this. The only thing that can ever effect me personally for more than one short passing day, is any doubt about my powers for poetry. [Letters, I, 404] 
Keats's description of himself here as "melt[ing] into the air with voluptuousness" appropriates the language of sexual union in order to justify and, in one sense, prove his ability to function as an undistracted, ambitious poet dedicated to his literary vocation.

In a more frivolous and light-hearted exchange with his brother in a letter of 18 September 1819 , Keats assiduously transcribed a lengthy passage of Burton's text which largely consisted of the itemizing of the parts of woman's body subject to corruption and decay. Of course, these are misogynous perceptions. The passage is prefaced with the proposition that "Every Lover admires his Mistress though she be very deformed of herself." There follows a considerable list of deformities, including:

pendulis mammis her dugs like two double jugs, or else no dugs in the other extream, bloody-falln fingers, she have filthy, long, unpaired, nails, scabbed hands or wrists, a tan'd skin, a rotten carcass, crooked back, she stoops, is lame, splea footed, as slender in the middle as a cow in the wast, gowty legs, her ankles hang over her shooes, her feet stink, she breed lice, a meer changeling, a very monster, an aufe imperfect, her whole complexion savors, an harsh voice, incondite gesture, vile gate, a vast virago, or an ugly tit, a slug, a fat fustilugs, a trusse, a long lean rawbone, a Skeleton, a Sneaker... [Letters, II,191]

Such an extensive rhetoric for the monstrous variety of woman's corrupt body must have been formative in his thinking about the central figure of his narrative of the man-devouring serpent-woman Lamia. This will be discussed later.

To sum up, in his letters, Keats articulates the anxieties, fears, and frustrations as well as the aggressive tendencies towards women. The above quoted passages from the Letters represent the most disturbing and negative of Keats's attitudes towards women. According to the Letters, the figure of woman (or the body?) represents the point of greatest disturbance. The split governing the figure of woman in his writing is determined by the distinction between the ideal and the real, or as he might put it, between the "ethereal" and the real [Letters, I, 341].

\section{In Lamia}

After reading those letters, it is not difficult to understand Keats's portrayal of Lamia-the serpent/woman since in the letters the relevant evidences could be discovered. That is to say, the letters can explain why Lamia has such an ambiguous identity.

Keats has betrayed himself in the letters his ambivalent attitudes to women-torn between the ideal and the real. Richard Turley in Keats's Boyish Imagination explores that "Keats identifies a conflict between his boyish conception of women as "pure goddesses" and his more mature, if troubled, notion of what he calls "their reality" [12] , thus Lamia follows the principle. Lamia's ambiguities are as follows:

\section{To begin with, the most ambiguous issue about Lamia is her identity-}

whether she is a serpent or a woman. Though most of the critics agree the ambivalence or the contradictions of Lamia, they give little concern to Lamia's original identity. Or few critics, as Karla Alwes in Imagination Transformed states Lamia's "primal identity" is a "serpent" while simultaneously naming her as "the 'rainbow-sided' female" [145,144]. It is not because the issue is unimportant to the understanding of Lamia that critics gave little exploration to the issue, but perhaps the critics missed certain messages of Keats and took for granted that Lamia is originally a serpent. Or maybe because Lamia is inspired by Burton's Anatomy of Melancholy in which Lamia is a serpent transformed into a woman, critics are influenced too deeply by the 
original story to presumably view Keats's Lamia as so. Though one critic, Tilottama Rajan detects the important passage which can reveal Lamia's primal identity, yet he misreads or misunderstands the message.

Rajan thinks Keats himself is uncertain whether Lamia is a serpent or a woman "because Lamia's existence as a woman precedes her existence as a serpent [I.117]" [127]. Here, he refers to the following lines:

I was a woman, let me have once more

A woman's shape, and charming as before. [I.117-118]

Rajan reads the lines as "she only claims to have been a woman 'once' (not originally)"[128]). If presumably considering Lamia as a serpent, "a woman" here of course can be understood as a female serpent; however, after reading "let me have once more/ A woman's shape, and charming as before" ("once more" means "again"?), we cannot help interpreting that Lamia's original identity is a woman as a human being, and not a woman serpent. Here she is asking Hermes to help her to resume her original figure-“a woman's shape, and charming as before". With the help of the two lines, we are clear that Lamia's primal identity is a woman (though the poem does not tell us how she was transformed into a serpent from a woman). So she is a "serpent/woman" instead of "serpent-woman" since the latter indicates her essential nature as a serpent. The issue of Lamia's primal identity is important to the understanding of the poem because it displays Keats's problems.

In Burton's story, Lamia is definitely a serpent assumed the guise of a woman. While in Keats's story, Lamia is originally a woman, but Keats's portrayal of Lamia still leads to so many readings of uncertainties of her identity. The problem comes out. It is due to Keats's own ambivalent attitudes to women that he deliberately creates Lamia as a combined figure of both serpent and woman and only vaguely implies to us her original identity as a woman. That is to say, to the anxious Keats, Lamia-a woman-also possesses the traits of a serpent. Of course it is known that serpent in western culture usually symbolizes the evil. Such treatment to Lamia reveals Keats's own perverse attitudes to women. On the other hand, Keats concerns not how Lamia was changed into a serpent or who victimized Lamia into a serpent while only employs two lines to indicate her original identity. This also betrays Keats's hostility to women. Maybe this point is a little far-fetched, but his choice of writing the story as it is instead of telling us how Lamia was victimized into a serpent could betray his intentions. To conclude, most readings of Lamia with ambiguous identity result from Keats's own deliberate description.

\section{The second ambiguity is with her shape or her body.}

Even when Lamia was in a serpent form, her body is a mixture of loveliness and repulsion.

She was a Gordian shape of dazzling hue, Vermilion-spotted, golden, green, and blue; Striped like a zebra, freckled like a pard, Eyed like a peacock, and all crimson barr'd; And full of silver moons, that as she breathed, Dissolv'd, or brighter shone, or interwreathed Their lustres with the gloomier tapestriesSo rainbow-sided, touch'd with miseries, She seem'd at once, some penanced lady elf, Some demon's mistress, or the demon's self. Upon her crest she wore a wannish fire 
Sprinkled with stars, like Ariadne's tiar:

Her head was serpent, but ah, bitter-sweet!

She had a woman's mouth with all its pearls complete:

And for her eyes: what could such eye do there

But weep, and weep, that they were born so fair?

As Proserpine still weeps for her Sicilian air. [I, 47-63]

Surely Jeffery Bakers' detection of "grotesquerie in the vision of a reptilian head with human lips, teeth, and weeping eyes" is right [38], while the above lines also create a funny effect. David Perkins observes "at least in the first part of the poem, she is described in a tone tinged with mockery"[145]. The quick movement of the verse, the incongruity of the menagerie, and the kaleidoscope of color all define an attitude toward her. Moreover, her array of patterns and colors, "golden, green, and blue", shifts, flickers, and dazzles as she breathes, and together with her over-lavish collection of other ornaments, her "silver moons" and her "crest...Sprinkled with stars," it seems to be a satire. She reminds one of a burlesque dancer. These wonders are topped by the bizarre absurdity of the mingling of woman and serpent.

If keeping his letter to George in mind, this is not difficult to understand. In the letter of 18 September, 1818, Keats lists a variety of woman body's deformities to his brother in hope that George might be "very much amused" [II, 191]. It is, he adds, a "feu de joie", or "fire of joy (my italicized )", by which he presumably means to indicate an enjoyable piece of satire. While it is exactly in the same letter, Keats says:

\section{I have been reading over a part of a short poem I have composed lately, called Lamia, and I am certain there is that sort of fire (my italicized) in it that must take hold of people some way. Give them either pleasant or unpleasant sensation - what they want is a sensation of some sort. [II, 191]}

It is interesting that in the same letter Keats at first states in his rewriting of Lamia there is a kind of "fire", while one page later he says "I have been reading lately Burton's Anatomy of Melancholy, and I think you will be very much amused with a page I here copy for you. I call it a Feu de Joie". His Lamia is inspired by Burton, and he uses the same word "fire" to describe his Lamia and the following deformities of woman body. Is it a simple coincidence? When composing Lamia, Keats must be influenced by Burton's description of those deformities, thus Keats creates a grotesque figure. So Lamia is rather a woman imprisoned in a serpent form instead of a serpent disguised as a woman. Keats deliberately creates an ambivalent Lamia of both a woman and a serpent. Even during Lamia's transformation into a woman, Keats's repulsion to woman's body goes on in the following lines:

Of all her sapphires, greens and amethyst.

And rubious-argent; of all these bereft,

Nothing but pain and ugliness were left,

Still shone her crown; that vanished, also she

Melted and disappeared as suddenly. [I.161-168]

Lamia undergoes a transformation, and is reduced to an ambiguous figure. Keats here gives an ambiguous description- "Nothing but pain and ugliness were left". When consider it carefully, we are unable to make sure its meaning because the word "left" itself is ambiguous. Does it mean the "pain and ugliness" dissolve while beauty remains or does it mean beauty vanishes while "pain and ugliness" remain? So if the word means "remained", it implies Keats's subconscious view that woman's body is ugly or deformed. 


\section{The third ambiguity of Lamia is about her immortality.}

Lamia is a goddess, possessing supernatural knowledge. Lamia can see the comings and goings of the gods, she can make a nymph visible or invisible, and she can "unperplex bliss from its neighbour pain" [I, 192]. However, though she has godlike capabilities, Lamia is not an "impenetrable" goddess [Alwes, 144]. Though she could succeed in protecting the nymph, when she encounters Apollonius, she is so fragile that Apollonius' one single gaze could pierce her into nothing, while Apollonius is only a mortal man. Here, Lamia's supernatural power even could not save herself from the mortal man's gaze, and she is only an ordinary mortal woman who cannot resist a man's visual invasion. To conclude, Lamia's ambiguity in her immortality is also caused by Keats's split attitudes to woman as shown in his letters, that is, the conflicting ideas of viewing woman between "a pure goddess" and the woman in "their reality" [Letters, I, 341].

\section{The fourth ambiguity of Lamia is about her moral nature.}

In the affair of Hermes and the nymph, Lamia on the one hand assumes protection of the nymph and generously shields her from sexual demands, from "the love glances of unlovely eyes, / Of Satyres, Fauns, and blear'd Silenus' sighs" [I, 102-3]. She does so by making the nymph invisible, thus protecting not only her chastity but, as she stresses, her privacy as well. Yet on the other hand, she plays the madam and sells the nymph to the flighty Hermes to gratify her own sexual longing. This portrayal indicates the fickleness or the changeability of the female character, following the misogynous tradition that usually criticizes the female fickleness. Thus when describing her appearance as a serpent, it says she was "full of silver moons" [I: 51]. Moon is usually viewed as a feminine symbol for its fickleness.

\section{CONCLUSION}

To sum up, Lamia is a woman changeable in her character, as well as in her body. She at least dissolves twice-into the shape of a woman in the beginning, and again at the end of the poem when her looks dissolve in the look of Apollonius, not including her transformation from a woman into serpent happened before the story. Andrew Bennett reads Lamia as "language, a construct of language, and her words, like her body, constantly threaten to melt, to dissolve so that neither Crete's forests, nor Keats's audience hear any more" [76]. This partly supports my reading because it also states the changeability of Lamia. So in Keats's opinion, women are fickle in character, and women's body ugly and repulsive. All these hostile opinions come from his discovery of women's "reality" which could hardly gratify his "Boyish imagination".

\section{References}

Alwes, Karla. Imagination Transformed: the Evolution of the Female Character in Keats's Poetry. Carbondale: Southern Illinois UP, 1993.

Baker, Jeffery. John Keats and Symbolism. Sussex: Harvester Press, 1986.

Bennett, Andrew. Keats, Narrative and Audience: the Posthumous Life of Writing. Cambridge: Cambridge UP, 1994.

Keats, John. Letters of John Keats: to his Family and Friends. London: Macmillan, 1935.

---.Complete Poems. Ed, Jack Stillinger. Cambridge: the Belknap Press of Harvard UP, 1982.

Perkins, David. The Quest for Permanence: the Symbolism of Wordsworth, Shelley, and Keats. Cambridge: Harvard UP, 1959.

Rajan, Tilottama. Dark Interpreter: the Discourse of Romanticism. Ithaca and London: Cornell UP, 1980.

Turley, Richard Marggraf. Keats's Boyish Imagination. London and New York: Routledge, 2004.

Whale, John. John Keats: Critical Issues. New York: Palgrave Macmillan, 2005. 